\title{
Women, Islam, and Abbasid Identity
}

\section{Nadia Maria El Cheikh}

Cambridge, MA: Harvard University Press, 2015. 176 pages.

The book under review, which is divided into five chapters, an introduction, and a conclusion, investigates how gender, sexuality, and concepts of womanhood were deployed to express cultural differences in order to formulate and articulate the Abbasid identity and legitimize the new dynasty's authority. El Cheikh argues that Abbasid-era texts used gendered metaphors and concepts of sexual difference to describe those groups they perceived as a threat.

The "Introduction" opens with an overview of the book's scope and is followed by the story of the "harlots of Hadramaut" rejoicing after the Prophet's death, how Abu Bakr dealt with it, and why this event was considered significant. These women's public celebration was contrasted with Muslim prescriptions for women as regards obedience, piety, and domesticity. The purpose here was to juxtapose the era of jähilizyah, with its idolatry, tribal feuds, sexual immorality, burial of live infant girls, and the absence of food taboos and rules of purity, to the mainstream Islamic cultural construction of the emerging community struggling to define itself. El Cheikh argues that the Abbasid textual tradition was unsympathetic toward the Umayyads and thus represented them as corrupt and godless in order to justify Abbasid rule, which would lead to a new society characterized by "the cohesive powers of a common language, currency and a unifying religio-political center" (p. 5).

The "Introduction" also juxtaposes the pre-Islamic gender system to the rights Islam provided to women in order to highlight their role in transmitting prophetic traditions and outlawing female infanticide, as well as their rights to property and economic support. In addition, the author also notes that Islamic rules and regulations stifled many of the pre-Islamic women's freedoms and power, thereby stressing the importance of Khadijah and other early Muslim women.

The first chapter, "Hind bint 'Utba: Prototype of the Jahiliyyah and Umayyad Woman," details how history was used for political, legal, and rhetorical concerns, reflecting third/ninth century debates. Negative images of this era were used as a counterpoint to the Islamic spirit, with which the Abbasids used to define themselves. Hind provides the jāhilizyah woman par excellence and is therefore featured in anti-Umayyad rhetoric - she was the first Umayyad caliph's mother - to construct an image of that era as an antithesis of knowledge and gentleness. 
However, El Cheikh reminds the reader that that era was not all bad, as its Arabic was purer and still in its pristine form. While Hind's behavior was constructed in such a way to reflect a prototype as yet untamed by Islam, Hind the Umayyad was used for anti-Umayyad rhetoric: the official Abbasid

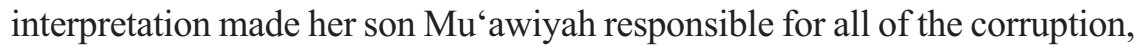
vanity, and decadence to discredit the whole dynasty. A friendlier image of the dynasty emerged after the Abbasids adopted what was to become Sunni "orthodoxy." Ramla bt. Abu Sufyan, one of the Prophet's wives, then became a medium for rehabilitating Abu Sufyan's family.

The second chapter, "Women's Lamentation and Death Rituals in Early Islam," shows the radical departure from pre-Islamic Arabia's religious and social mores and how the ummah's identity was to be defined partly by its adherence to specific social and ritual practices, notably death rituals. Muslims rejected ritual mourning for it was grounded in an ideology that was incompatible with the new emphasis on salvation in the afterlife. Therefore, women's wailing and lamenting were deemed offensive because they represented a complaint against God's judgment, His decree and wisdom.

According to the author, the purpose of this injunction was to contain mourning. Lamentation allowed women to articulate their sorrow, incite rage, and reveal their vulnerability when faced with the death of a loved one. The Islamic answer to Hind's excessive lamentations after Badr is reflected in Safiyyah's response to the mutilation of her brother Hamza at Uhud: modified behavior, patience, restraint, and forbearance.

El Cheikh argues that this devaluation of feminine utterance is the consequence of anchoring the female voice in the female body, thereby conferring upon it the conventional associations of femininity with emotion and irrationality that constitutes an offense against the new Muslim community. Hence, only the official male poet grieves when the Prophet dies, thereby eliminating the role of women in mourning rituals. The author shows how the Shi' $i$ community carried lamentation to a far higher level after al-Husayn's martyrdom at Karbala, which the Sunnis deemed excessive and dangerously extreme.

The third chapter, "The Heretical Within: The Qaramita and the Intimate Realm," deals with the image of this Ismaili sect as portrayed in the Sunni sources. She shows that heresy, when acknowledged and attacked, gains greater visibility and prominence. But its exposition does not necessarily represent the actual threat it poses to an established regime or orthodoxy, for the goal of heresiological literature is to misrepresent the "heretics," exaggerate their number, indulgent behavior, convictions, and sphere of influence. Although the author 
claims that there is no specific Islamic term for heresy (p. 60), she qualifies this (p. 61) by saying that the Arabic term zandaqah comes close to defining it. This word, which originally meant believers in dualist doctrines who nominally professed Islam, was later generalized to include holders of unorthodox, unpopular, and suspect beliefs until it eventually designated unbelief.

El Cheikh argues that the $i j m \bar{a}^{\prime}$ (consensus) of classical Sunni jurists had the ultimate claim on defining Islamic orthodoxy, considering all other opinions as heterodox. When Sunni orthodoxy was consolidated in the fourth/tenth century, heresiography employed set designations for those they considered opponents. But consistency in this regard was never achieved. She then provides the Qaramita's historical background. The anti-Isma'ili propaganda designed to discredit its members condemned them as heretics and dealt with their women and their sexual conduct, accusing them of heresy, immoral behavior, sexual promiscuity, communal sex acts, and wife-sharing. El Cheikh argues that heresy was sexualized so that it would function as a cultural marker. Manipulating the categories of women, gender, and sexuality played an important role in constructing orthodoxy. Hence, orthodoxy was defined, in part, to stand in contrast to the Qaramita's understandings of these same categories.

The fourth chapter, "Beyond Borders: Gender and the Byzantines," reveals that the Abbasids approached Byzantium, their main imperial rival, in a more nuanced manner despite their misconstrual of Byzantine reality. They distinguished between dār al-Islām (Muslim-ruled lands) and dār alharb (non-Muslim-ruled lands), two separate identities that recognized the dhimmīs - notably Jews, Christians, Zoroastrians, and Sabians - while accusing the Christians of deviating from true Christianity and corrupting the scriptures. Despite the continuous commercial relations, exchange of embassies, ransom of war prisoners, deportation of conquered populations, and using Byzantine women as harem slaves, the Islamic representation of Byzantine women and gender relations served as a polemical focus to belittle Byzantine culture as being dominated by moral licentiousness, permissiveness, and decadence. In terms of this supposed decadence, focus was placed on certain sexual tropes, prostitution, drinking wine, and singing. The description of the Byzantine's sexual difference also served as a ploy in constructing the Abbasid norm, even though Arab Muslims did not see this rival empire and its history as barbaric, uncivilized, and inferior. Rather, they saw both empires as equal but different.

Chapter 5, "Fashioning a New Identity: Women Exemplars and the Search for Meaning," analyzes the construction of female exemplars in early Abbasid sources to both uphold and preserve communal religious and ethical bound- 
aries and to define one's place in relation to other religious communities. The sources cited articulate a metanarrative of the primordial Islamic past, one centered on the events of the Prophet's life and the period immediately following his death. The primary female exemplars Khadijah, 'A'ishah, and Fatimah, are all linked to the Qur'anic Mary using various themes.

Other female Qur'anic models symbolize facets of the Islamic order and represent a means toward its preservation. ' $A$ 'ishah's controversial role - the hadith al-ifk (the affair of the lie) and her involvement in the Battle of the Camel - is reformed and improved, and both Khadijah and Fatimah are idealized as well as compared and contrasted with pre-Islamic women. These exemplary women, now role models and powerful feminine prototypes to be emulated, remain crucial for contemporary Muslim practice and politics.

In the "Conclusion," El Cheikh reiterates her main themes and conclusions: (1) identity formation is integrally linked to gender relations and sexuality and (2) the Abbasid narrative was built upon selection and exclusion in order to fix women's place and role in society. The female personalities and groups featured serve as markers of changing ideological boundaries of the Islamic narrative versus the non-Muslim others.

This book is an interesting read and shows how history can be read differently through the lens of gender issues. The author's very ambitious project sought to cover a wide range of topics that can be addressed reasonably and in a detailed manner. Although she did not fully develop some of the topics, the book is to be recommended for those interested in early and medieval Muslim history and gender issues.

Yasmin Amin

Doctoral Candidate, Arabic and Islamic Institute Exeter University, Exeter, United Kingdom 